\title{
Targeted ${ }^{18} \mathrm{O}$-Labeling for Improved Proteomic Analysis of Carbonylated Peptides by Mass Spectrometry
}

\author{
Mikel R. Roe, ${ }^{\text {a }}$ Thomas F. McGowan, ${ }^{\text {b }}$ LaDora V. Thompson, ${ }^{\mathrm{c}}$ and \\ Timothy J. Griffin ${ }^{a}$ \\ a Department of Biochemistry, Molecular Biology, and Biophysics, University of Minnesota, Minneapolis, \\ MN, USA \\ ${ }^{\mathrm{b}}$ Center for Mass Spectrometry and Proteomics, University of Minnesota, Minneapolis, MN, USA \\ ${ }^{\mathrm{c}}$ Department of Physical Medicine and Rehabilitation, University of Minnesota, Minneapolis, MN, USA
}

Proteomic characterization of carbonylated amino acid sites currently relies on confidently matching tandem mass spectra $\left(\mathrm{MS}^{2}\right)$ to peptides within a sequence database. Although effective to some degree, reliable proteomic characterization of carbonylated peptides using this approach remains a challenge needing new, complementary solutions. To this end, we developed a method based on partial ${ }^{18} \mathrm{O}$-labeling of reactive carbonyl modifications, which produces a unique isotope signature in mass spectra of carbonylated peptides and enables their detection without reliance on matching MS $^{2}$ spectra to a peptide sequence. Key to our method were optimized measures for eliminating trypsin-catalyzed incorporation of ${ }^{18} \mathrm{O}$ at peptide $\mathrm{C}$-termini, and for stabilizing the incorporated ${ }^{88} \mathrm{O}$ within the carbonyl modification to prevent its loss during liquid chromatography separation. Applying our method to a rat skeletal muscle homogenate treated with the carbonyl modification 4-hyroxynonenal (4-HNE), we demonstrated its compatibility with solid-phase hydrazide enrichment of carbonylated peptides from complex mixtures. Additionally, we demonstrated the value of ${ }^{18} \mathrm{O}$ isotope signatures for confirming HNE-modified peptide sequences matched via sequence database searching, and identifying modified peptides missed by $\mathrm{MS}^{2}$ and/or sequence database searching. Combining our ${ }^{18} \mathrm{O}$-labeling method with a customized automated software script, we systematically evaluated for the first time the efficiency of $\mathrm{MS}^{2}$ and sequence database searching for identifying HNE-modified peptides. We estimated that less than half of the modified peptides selected for $\mathrm{MS}^{2}$ were successfully identified. Collectively, our method and software should provide valuable new tools for investigators studying protein carbonylation via mass spectrometry-based proteomics. (J Am Soc Mass Spectrom 2010, 21, 1190-1203) () 2010 American Society for Mass Spectrometry

$\mathrm{T}$ he post-translational introduction of reactive ketone and aldehyde moieties into proteins, known as protein carbonylation, is a classic marker of oxidative stress that correlates well with both the aging process itself as well as various age-associated diseases, ranging from Alzheimer's disease and Parkinson's disease to amyotrophic lateral sclerosis and diabetes [1]. While a definitive role in disease etiology has yet to be established, the deleterious effect carbonylation has on protein function provides a putative biochemical mechanism through which this irreversible modification may contribute towards the initiation and propagation of disease [2]. To further characterize the basic biology of protein carbonylation and thus better define its potential pathologic role, the specific proteins and amino

Address reprint requests to Dr. T. J. Griffin, Department of Biochemistry, Molecular Biology, and Biophysics, University of Minnesota, Minneapolis, MN 55455, USA. E-mail: tgriffin@umn.edu acids carbonylated throughout disease progression need to be identified [2].

Characterizing protein carbonylation on a proteomewide scale is a core objective in the emerging field of redox proteomics, which seeks to characterize proteins susceptible to oxidative or nitrosative modifications [3]. Tandem mass spectrometry $\left(\mathrm{MS}^{2}\right)$-based proteomics enables both the identification of carbonylated proteins and the localization of the corresponding carbonyl to a specific amino acid, thus providing a powerful tool in redox proteomics. However, such studies for protein carbonylation are not routine, as several challenges complicate the process.

One challenge is due to the complexity of carbonyl modifications, which involves a number of mechanisms generating various chemically unique reactive carbonyls of differing masses that target several amino acids. For example, carbonyls may be directly introduced into the side chains of Lys, Arg, Pro, and Thr via metal catalyzed oxidation, and into the side chain of Glu and 
the $\mathrm{N}$-termini of peptides via $\alpha$-amidation of the protein backbone [4, 5]. Alternatively, reactive carbonyl intermediates derived from protein glycation and lipid peroxidation target the side chains of Lys and Arg, and Cys, His, Lys, and Arg, respectively [6-9]. Importantly, most of these reactive carbonyl moieties (in the form of aldehydes or, to a lesser extent, ketones) retain their reactivity following conjugation, and are thus susceptible to subsequent Schiff-base bond formation.

Another challenge lies in the relatively low abundance of carbonylated proteins within complex biological mixtures. To address this challenge, front-end enrichment methods that target this substechiometric protein population have been developed. Primarily, these methods rely on covalent chemistry-based enrichment methods exploiting the reactivity of hydrazides with reactive carbonyls, enabling the global analysis of carbonylated proteomes [2]. One common approach is to enrich carbonylated proteins labeled with reagents such as biotin-hydrazide, or variations thereof, via avidin-affinity chromatography before their identification by mass spectrometry. This approach has proven useful for characterizing the carbonyl proteomes of various mammalian-derived protein lysates generated from plasma [10], tissue homogenates [11-13], mitochondrial extracts [14], and tissue-derived cell lines $[15,16]$. An important caveat regarding the biotinhydrazide approach is that carbonylation of the proteins identified is inferred based on their enrichment by avidin alone, as the specific carbonylated residue is very rarely identified due to signal suppression from the remaining non-carbonylated peptides in the sample. Also, biotin-hydrazide itself readily fragments into a number of abundant ions, which can preclude identification of biotin-hydrazide labeled peptides [17].

Efforts to unequivocally identify sites of carbonylation to specific residues have thus relied on methods for enriching carbonylated peptides, followed by $\mathrm{MS}^{2}$ analysis and matching to peptide sequences via automated sequence database searching. One promising approach, involving the avidin-affinity enrichment of biotinylated peptides, rather than labeled proteins, has been used to successfully localize sites of carbonylation within both simple and complex protein mixtures [18, 19]. However, the aforementioned fragmentation of biotinylation reagents in $\mathrm{MS}^{2}$ spectra and increased hydrophobicity from the label complicate this method [17].

As an alternative to label-based enrichment approaches, we developed a label-free solid-phase hydrazide $(\mathrm{SPH})$ reagent that directly and reversibly captures carbonylated peptides via formation of Schiff-base bonds [20], and demonstrated its utility on a complex mixture of HNE-modified proteins. Importantly, captured peptides are released from the reagent by hydrolyzing the Schiff-base, and are thus restored to their native form as the carbonyl is replenished. While this label-free method eliminated fragment ions in the $\mathrm{MS}^{2}$ spectra derived from a biotinylating reagent, we observed that many seemingly high quality $\mathrm{MS}^{2}$ spectra, for unknown reasons, still did not confidently match to HNE-modified peptide sequences.

Based on these collective observations concerning the challenges of identifying carbonylated peptides, new methods to assist in their detection and identification are needed. Here we have sought to develop a method by which enriched, carbonylated peptides could be unambiguously detected by mass spectrometry, without a dependence on successfully matching their $\mathrm{MS}^{2}$ spectra to sequences via database searching. Such a method would have potential value in: (1) confirming the presence of carbonylated peptides that are matched via database searching; (2) differentiating enriched, carbonylated peptides from noncarbonylated background peptides, which could then be further targeted for $\mathrm{MS}^{2}$ analysis; and (3) evaluating the efficiency by which these peptides are identified by $\mathrm{MS}^{2}$ and facilitating studies for improving their $\mathrm{MS}^{2}$-based identification.

Our method takes advantage of the nonenzymatic solvent exchangeable properties of reactive carbonyl oxygens, enabling the partial incorporation of ${ }^{18} \mathrm{O}$ into carbonylated peptides and resulting in an isotope signature detected in MS or $\mathrm{MS}^{2}$ spectra unique to these modified peptides. Using HNE-modified myoglobin as a standard, and a HNE-modified complex protein mixture derived from rat skeletal muscle, we have developed an optimized protocol for the specific and stable incorporation of ${ }^{18} \mathrm{O}$ into reactive carbonyls that complements label-free enrichment methods and improves the detection of carbonylated peptides. Our results demonstrate the value of this method for confirming putatively HNE-modified peptide sequences identified from $\mathrm{MS}^{2}$ spectra, decreasing false negative identifications of such sequences, and providing a novel means to assess the efficiency of the identification of these peptides via $\mathrm{MS}^{2}$ and sequence database searching. As such, our method provides a valuable new tool for investigators endeavoring to study protein carbonylation via mass spectrometry-based proteomics.

\section{Materials and Methods}

\section{Preparation of ${ }^{18} \mathrm{O}$-Labeled HNE-Modified Myoglobin Digest}

Five-hundred $\mu \mathrm{g}$ of myoglobin from horse heart (SigmaAldrich Corp., St. Louis, MO, USA) was treated with 2 mM 4-hydroxynonenal (HNE, Cayman Chemical Company, Ann Arbor, MI, USA) for $2-\mathrm{h}$ at $37^{\circ} \mathrm{C}$ in $100 \mathrm{mM}$ sodium phosphate, $\mathrm{pH}$ 7.2. The modified sample was filter centrifuged using an Amicon Ultra spin column with a $10 \mathrm{kD}$ cutoff (Millipore, Billerica, MA, USA) to remove excess $\mathrm{HNE}$, and the resulting retentate was reconstituted in $100 \mathrm{mM}$ sodium phosphate, $\mathrm{pH}$ 7.2. After measuring the protein concentration by the BCA assay (Thermo Fisher Scientific Inc., Rockford, IL, USA), the entire HNE-modified myoglobin sample was tryp- 
sinized overnight (1:50 protease-to-substrate) and subsequently stored at $-20{ }^{\circ} \mathrm{C}$ for future experiments.

\section{${ }^{18}$ O-labeling of HNE-Peptides}

The following protocol for labeling HNE-modified peptides with ${ }^{18} \mathrm{O}$ was applied to a $2 \mu \mathrm{g}$ aliquot from the HNE-modified myoglobin digest and to the enriched peptide fraction from the HNE-modified rat skeletal muscle tissue lysate. Lyophilized samples were reconstituted in $100 \mu \mathrm{L}$ of ${ }^{18} \mathrm{O}$-labeling buffer $(70 \%$ vol/vol of $97 \% \mathrm{H}_{2}{ }^{18} \mathrm{O}$ (Sigma), $100 \mathrm{mM}$ sodium phosphate, $\mathrm{pH} 7.2$ ) and then incubated at room-temperature for $2 \mathrm{~h}$. Next, a small volume of concentrated sodium hydroxide was added to adjust the sample $\mathrm{pH}$ to about 8 , followed by the addition of alkaline sodium borohydride to a final concentration of $10 \mathrm{mM}$. After incubating at room temperature for an additional hour, the samples were desalted by $\mathrm{C}_{18}$ ziptips and the resulting elates vacuum centrifuged to dryness. To back-exchange any ${ }^{18} \mathrm{O}$ molecules incorporated into peptide carboxylates during labeling, each sample was reconstituted in $100 \mu \mathrm{L}$ $\mathrm{H}_{2}{ }^{16} \mathrm{O}$ supplemented with $1 \mu \mathrm{g}$ Trypsin, incubated at room-temperature for $24 \mathrm{~h}$, vacuum centrifuged to dryness, and stored at $-20^{\circ} \mathrm{C}$.

\section{Comparing Methods for Eliminating the Oxygen-Exchange Activity of Trypsin}

One-hundred $\mu \mathrm{g}$ of the HNE-modified myoglobin digest was spiked with 2 additional $\mu \mathrm{g}$ of trypsin and divided into $20 \mu \mathrm{g}$ aliquots, each subjected to a different method for depleting the oxygen-exchange activity of trypsin. One $20 \mu \mathrm{g}$ aliquot was diluted to $1 \mathrm{~mL}$ with water and filter centrifuged using an Amicon Ultra filter spin column (10 kDa cutoff) per manufacturer's specifications. Following a single pass through the spin column, the peptides in the flow-through fraction were vacuum centrifuged to dryness and split into four aliquots. The first aliquot was ${ }^{18} \mathrm{O}$-labeled according to the protocol described above. The second aliquot was vacuum centrifuged to dryness and subsequently reconstituted in alkaline ${ }^{18} \mathrm{O}$-labeling buffer (supplemented with $100 \mathrm{mM}$ sodium hydroxide, $\mathrm{pH}>12$ ). This sample was then reduced and processed for analysis according to the ${ }^{18} \mathrm{O}$-labeling protocol described above. The third aliquot was boiled for $15 \mathrm{~min}$ before labeling with ${ }^{18} \mathrm{O}$ so as to denature the trypsin and thus render it inactive. Seventy $\mu \mathrm{L}$ of $\mathrm{H}_{2}{ }^{18} \mathrm{O}$ and $10 \mu \mathrm{L} 1 \mathrm{M}$ sodium phosphate, $\mathrm{pH} 7.2$, was then directly added to the boiled sample so as to establish ${ }^{18} \mathrm{O}$-labeling conditions consistent with those used for the other methods. Again, the sample was reduced and analyzed according to the ${ }^{18} \mathrm{O}$-labeling protocol described above. A fourth aliquot was ${ }^{18} \mathrm{O}$-labeled according to the protocol described above without concern for ${ }^{18} \mathrm{O}$ incorporation into the C-terminus of peptides by trypsin-catalyzed oxygen exchange. The reduced, ${ }^{18} \mathrm{O}$-labeled sample was then desalted by $C_{18}$ ziptip and the eluate vacuum centrifuged to dryness. The dried sample was subsequently reconstituted with $100 \mu \mathrm{L}$ of $100 \% \mathrm{H}_{2}{ }^{16} \mathrm{O}$ supplemented with $2 \mu \mathrm{g}$ trypsin, incubated overnight at room temperature, and vacuum centrifuged to dryness. All ${ }^{18} \mathrm{O}$-labeled peptides from each aliquot were analyzed according to the MALDI-TOF protocol described herein.

\section{Preparation of HNE-Treated Lysate from Rat Skeletal Muscle Tissue}

Twelve-month-old, adult Fisher 344 rats were purchased from the Minneapolis Veterans Administration Rodent Colony, and fully accredited by the Association for Assessment and Accreditation of Laboratory Animal Care International. The study was approved by the University of Minnesota Institutional Animal Care and Use Committee. Skeletal muscle tissue from both slowtwitch (soleus) and fast-twitch (tibialis anterior) muscle fibers were isolated from rat hind limb muscles. Oneand-a-half grams of combined muscle tissue was then minced with scissors and washed thrice with ice-cold 1X PBS (Sigma) by pelleting the tissue each time at $200 \mathrm{~g}$. The final tissue pellet was reconstituted in Tissue Lysis Buffer [1:10 wt/vol, $150 \mathrm{mM}$ sodium chloride, 50 $\mathrm{mM}$ Tris- $\mathrm{HCl}$ pH 7.4, 1 mM EDTA, 1\% Triton X-100, 1\% deoxycholic acid, $0.1 \%$ sodium dodecylsulfate, and $1 \times$ protease inhibitor cocktail (Roche)] and vortexed vigorously for $20 \mathrm{~s}$. Next, the tissue was homogenized using a PowerGen tissue homogenizer (Thermo Fisher Scientific Inc., Rockford, IL, USA) on the lowest setting with two $20 \mathrm{~s}$ mixes. The cellular debris was then pelleted by centrifuging the sample at $700 \times g$ for $10 \mathrm{~min}$ at $4{ }^{\circ} \mathrm{C}$. The supernatant was carefully removed and the proteins extracted by methanol-chloroform precipitation as previously described [14]. The resulting delipidated protein pellet was reconstituted in $100 \mathrm{mM}$ sodium phosphate, $\mathrm{pH} 7.2$, containing $0.1 \%$ SDS and quantified by the BCA assay. HNE-modified proteins were then generated by incubating $3 \mathrm{mg}$ of the tissue lysate with $250 \mu \mathrm{M}$ HNE for $2 \mathrm{~h}$ at $37^{\circ} \mathrm{C}$. Excess HNE was subsequently removed by filter centrifugation using an Amicon Ultra (Millipore, Billerica, MA, USA) spin column (10 kD cutoff) per manufacturer's instruction. The retentate was diluted to $2 \mathrm{~mL}$ with trypsin friendly buffer (100 mM sodium phosphate $\mathrm{pH}$ 7.2, 5 mM TCEP, $10 \%$ acetonitrile) and then digested overnight following the addition of $60 \mu \mathrm{g}$ of trypsin.

\section{Enrichment of HNE-Modified Peptides from HNE-Treated Rat Skeletal Muscle Tissue Lysate}

Carbonylated peptides within the HNE-treated tissue lysate digest were enriched using UltraLink Hydrazide Gel (Thermo Fisher Scientific Inc., Rockford, IL, USA), a commercially available solid-phase hydrazide reagent that is traditionally used for building antibody affinity 
columns. Briefly, $500 \mu \mathrm{L}$ of hydrazide gel slurry was washed with water in a $1.5 \mathrm{~mL}$ Eppendorf tube by vortexing vigorously. The resin was then pelleted by bench-top microcentrifugation, resuspended with 500 $\mu \mathrm{L}$ of the sample digest buffer $(100 \mathrm{mM}$ sodium phosphate, $\mathrm{pH}$ 7.2), combined with the sample digest, and mixed overnight on an Eppendorf Thermomixer R tube shaker (1200 RPM, $25^{\circ} \mathrm{C}$ ). After spinning down the resin, the non-bound peptides in the supernatant were removed and saved for future analysis. The remaining resin pellet was washed four times each with $1 \mathrm{~mL}$ of $1 \%$ SDS, $1 \mathrm{M} \mathrm{NaCl}, 80 \%$ acetonitrile, and distilled water by vigorous vortexing (20 s), and bench-top microcentrifugation in succession. To release the hydrazidebound peptides $1 \mathrm{~mL}$ of $1 \%$ acetic acid was added to the washed resin and the mixture was incubated for two hours on an Eppendorf Thermomixer $\mathrm{R}$ tube shaker (1200 RPM, $25^{\circ} \mathrm{C}$ ). Importantly, 1\% acetic acid proved optimal for releasing UltraLink Hydrazide (Pierce) bound peptides while minimizing the resin-derived contaminants generated by stronger acidic conditions. Such contaminates, although not specifically identified, are manageable under these less acidic conditions such that clean, database-searchable spectra can be obtained. After spinning down the resin, the enriched peptides present in the supernatant were collected and the resin was washed $1 \times$ with an additional $300 \mu \mathrm{L}$ of distilled water. The wash supernatant as added to the released peptides and the combined solution was vacuum centrifuged to dryness.

\section{MALDI-TOF MS/MS}

The lyophilized ${ }^{18} \mathrm{O}$-labeled HNE-treated myoglobin digests were reconstituted with $1.5 \mu \mathrm{L}$ of MALDI sample buffer ( $80 \%$ acetonitrile, $0.1 \%$ trifluoroacetic acid), mixed with $\alpha$-cyano-4-hydroxycinnamic acid matrix, and spotted on a MALDI plate. Both full-scan and $\mathrm{MS}^{2}$ spectra were collected in the positive ion detection mode on a Qstar XL quadrupole-TOF mass spectrometer fitted with a MALDI ion source (Applied Biosystems Inc., Foster City, CA, USA). Spectra were generated using the instrument parameters previously described [20].

\section{LC-MS/MS}

Enriched peptides from the HNE-treated rat skeletal muscle tissue lysate were reconstituted in $5 \mu \mathrm{L}$ of sample buffer ( $2 \% \mathrm{ACN}, 0.1 \%$ formic acid, aqueous) and fractionated by microcapillary liquid chromatography $(\mu \mathrm{LC})$ using an Eksigent (Eksigent Technologies, Dublin, CA, USA) nanoLC-1D plus HPLC. Specifically, peptides were fractionated by reversed-phase using an in-line analytical capillary column $(100 \mu \mathrm{m} \times 13 \mathrm{~cm})$ packed in-house with Magic $C_{18}$ resin (5 $\mu \mathrm{m}, 200 \AA$ Magic $\mathrm{C}_{18}$ AG; Michrom BioResource, Auburn, CA, USA). A linear gradient of $40 \%$ buffer B $(80 \% \mathrm{ACN}$, $0.1 \%$ formic acid, aqueous) at a flow rate of $250 \mathrm{~nL} / \mathrm{min}$ over $60 \mathrm{~min}$ was used to electrospray peptides directly into a linear ion trap mass spectrometer equipped with an Orbitrap mass analyzer (LTQ-Orbitrap, Thermo Electron Corp., San Jose, CA, USA). A top five datadependent method incorporating a $30 \mathrm{~s}$ dynamic exclusion window was used to continuously select the top five most abundant precursor ions in the Orbitrap (AGC target; $1 \times 10^{6}$ ions, resolution; 60,000, maximum ion accumulation time; $500 \mathrm{~ms}$, minimum threshold intensity; 1000) for $\mathrm{MS}^{2}$ fragmentation in the linear ion trap (AGC target; $1 \times 10^{4}$, maximum ion accumulation time; $100 \mathrm{~ms}$, normalized collision energy; 35, precursor isolation width; $2 \mathrm{~m} / \mathrm{z}$, microscan per spectrum; 1 ). Ions carrying either singly or unassigned charges were excluded from $\mathrm{MS}^{2}$ fragmentation.

\section{Database Searching and Data Analysis}

All $\mathrm{MS}^{2}$ data files extracted from the RAW file for the HNE-modified rat skeletal muscle sample were searched using the SEQUEST algorithm (ver. 27, rev.12, Thermo Fisher Scientific Inc., Rockford, IL, USA) against a concatenated $R$. norvegicus database (Refseq, Release 22, March 5, 2007), containing a composite 77,763 protein sequences. A number of variable modifications were specified in the search parameters including the oxidation of methionine $(+15.9949)$, the addition of ${ }^{18} \mathrm{O}$-labeled and reduced HNE $(+160.1349)$ to Cys, His, and Lys residues, and the incorporation of one ${ }^{18} \mathrm{O}$ molecule into the peptide C-terminus $(+2.0042)$. Mass tolerances of $0.8 \mathrm{Da}$ and 1.0 Da were used for the precursor and fragment ions, respectively, and a partially tryptic constraint was applied. A statistical measure of confidence was assigned for all prospective database matches via the Peptide Prophet scoring algorithm, and the resulting data were evaluated and organized using Scaffold (ver. 2_02_03; Proteome Software, Portland, OR, USA). To obtain a high confidence dataset, an 8 ppm mass accuracy constraint was applied to the subset of spectra matching to carbonylated peptides, which resulted in zero hits to the reverse database. This dataset was subsequently used to compare against the number of spectra containing ${ }^{18} \mathrm{O}$ isotope signatures as detected by our software.

To systematically identify candidate ${ }^{18} \mathrm{O}$ fragment patterns, a Python (2.5.2 ver.) program was written and run against the collected data files. The program, findIsoptopePatterns.py, takes as input an $m z X M L$ file and outputs a tab delimited file listing candidate MS and $\mathrm{MS}^{2}$ scans. First, the program identifies MS scans that have produced one or more MS ${ }^{2}$ scans. Then, for each precursor value in the MS scan, the program looks for an $m / z$ value that is a fixed Da difference below the precursor's $m / z(2 \pm 0.01 \mathrm{Da})$. In addition, the program checks that the intensity value is a fixed percentage of the precursor's intensity $(20 \%-80 \%)$. Second, the program examines the $\mathrm{MS}^{2}$ peak list identifying ${ }^{18} \mathrm{O}$ ion quartets. Peaks in the quartet must be separated by a set Da distance $(1 \pm 0.3 \mathrm{Da})$. This distance, and tolerance, can be set as a program parameter. The intensities for each of the 
4-tuple peaks is normalized to the third peak's intensity value. To be considered a legitimate candidate pattern, the first peak's intensity must be within a minimum and maximum percentage of the third peak $(20 \%-80 \%)$. These threshold values are modifiable parameters. To avoid the higher propensity of detecting false patterns in the lower $\mathrm{m} / \mathrm{z}$ range, the program only counts and reports the number of candidate fragment patterns above the precursor $m / z$ for each $\mathrm{MS}^{2}$ scan, as well as the MS pattern discovered in the first step.

\section{Results and Discussion}

\section{Targeted ${ }^{18}$ O-labeling of Protein Carbonyls}

Our method induces the partial incorporation of ${ }^{18} \mathrm{O}$ into reactive carbonyls on peptides by hydrating the peptides in a controlled amount of ${ }^{18} \mathrm{O}$ water (Figure 1a). Specifically, a mass tag specific to carbonylated peptides is introduced by incubating peptide mixtures in a neutral buffer containing a mixture of $70 \% \mathrm{H}_{2}{ }^{18} \mathrm{O} /$ $30 \% \mathrm{H}_{2}{ }^{16} \mathrm{O}$, resulting in an approximate $2: 1{ }^{18} \mathrm{O}:{ }^{16} \mathrm{O}$ ratio within the reactive carbonyl. The relative amount of ${ }^{18} \mathrm{O}(70 \%)$ used to label reactive carbonyls ensures that the resulting ${ }^{18} \mathrm{O}$ isotope signature generated is specific to carbonylated peptides, and is thus distinguishable from any other naturally occurring peptide isotope distributions observed within the typical $\mathrm{m} / \mathrm{z}$ range used for tandem mass spectrometry experiments. Importantly, this ratio is preserved by subsequently reducing the carbonylated peptides with $10 \mathrm{mM}$ sodium borohydride. Once reduced, the carbonylated peptides are amenable for additional LC-based fraction-

(a)

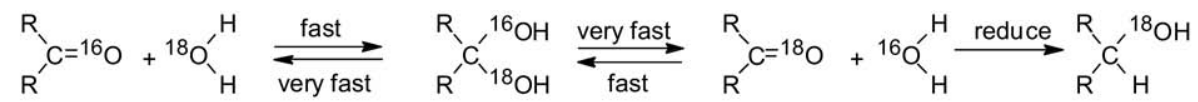

(b)
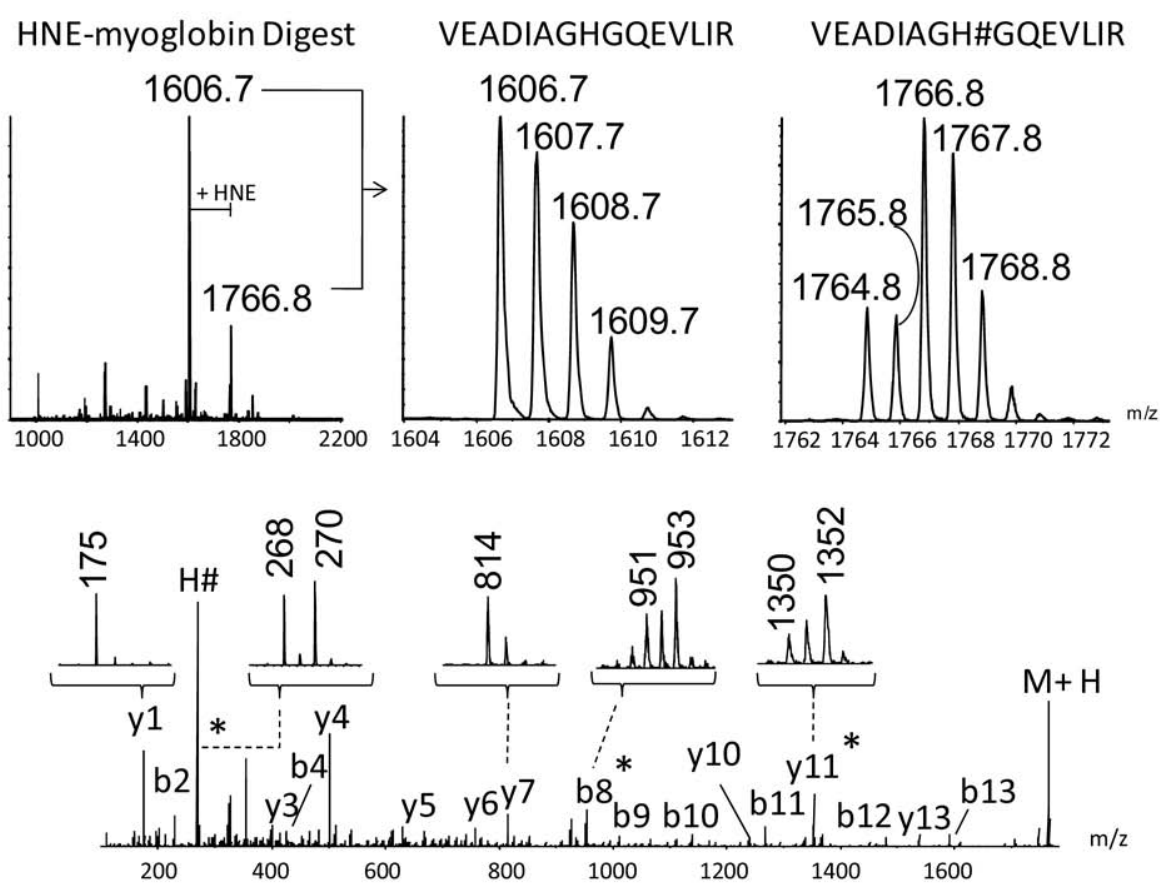

(c)

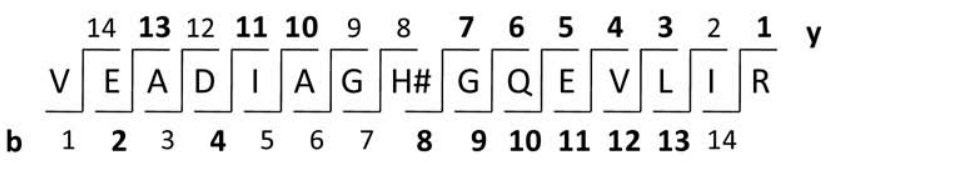

Figure 1. Targeted labeling of carbonylated peptides by stable incorporation of ${ }^{18} \mathrm{O}$. (a) Reaction mechanism for the stable incorporation of ${ }^{18} \mathrm{O}$ into carbonyl oxygen. Water supplemented with ${ }^{18} \mathrm{O}$ reacts with carbonyls to form an intermediate hydrate which undergoes condensation. The resulting ${ }^{18} \mathrm{O}-$ labeled carbonyl is reduced to trap the ${ }^{18} \mathrm{O}$ in an alcohol moiety. (b) MS spectrum of HNE-modified myoglobin digest labeled with $70 \% \mathrm{H}_{2}{ }^{18} \mathrm{O}$, focusing on the isotope envelopes from the non-modified and HNEmodified (\#) versions of a single peptide. (c) MS2 spectrum of ${ }^{18} \mathrm{O}$-labeled (70\%) HNE-modified peptide $(1766.8 \mathrm{~m} / \mathrm{z})$, focusing on the isotope envelopes of select fragment ions that demonstrate the utility of $70 \%$ ${ }^{18} \mathrm{O}$-labeling for tracking the HNE-modification. All $\mathrm{b}$ and $\mathrm{y}$ fragment ions observed are shown in bold in the peptide map below the spectrum. H\# designates the HNE-modified immonium ion of His. *HNE labeled fragments expected to show ${ }^{18} \mathrm{O}$ isotope signatures. 
ations without concern of further back-exchange with aqueous solvents, overcoming a limitation of past attempts to use ${ }^{18} \mathrm{O}$-labeling of carbonylated peptides [21]. Thus, the resulting ${ }^{18} \mathrm{O}$ isotope signatures produced in the MS and $\mathrm{MS}^{2}$ spectra are diagnostic of carbonylated peptides and provide additional depth of information from these spectra. A caveat of this method is that carbonyls either involved in crosslinks or lost due to retro Michael-addition chemistry are not subject to analysis [22].

To demonstrate the effectiveness of our ${ }^{18} \mathrm{O}$-labeling procedure, a digest of HNE-modified myoglobin was incubated in $70 \% \mathrm{H}_{2}{ }^{18} \mathrm{O}$ for $2 \mathrm{~h}$ followed by reduction in $10 \mathrm{mM}$ sodium borohydride for an additional hour. The resulting MS spectrum for the entire digest, together with the magnified isotope envelopes for the nonmodified and HNE-modified forms of the peptide VEADIAGHGQEVLIR are presented in Figure $1 \mathrm{~b}$. The specific partial incorporation of ${ }^{18} \mathrm{O}$ into the HNEmodified form of the peptide produced a unique isotope signature, characterized by a $+2 \mathrm{Da}$ isotopologue that measured about twice the intensity of the monoisotopic ion, making it readily distinguishable from the non-modified form (Figure 1b). Importantly, this isotope signature was retained in the $\mathrm{MS}^{2}$ spectrum for fragments that carry the carbonyl modification, and thus provides a tool for validating database search results (Figure 1c). Both the presence of a carbonyl modification and the exact residue to which the carbonyl is localized can be determined. This concept is demonstrated in the $\mathrm{MS}^{2}$ spectrum generated by the aforementioned HNE-modified peptide where fragments from the nonmodified portion of the peptide (e.g., y1 and y7) show normal isotope signatures, while those from HNE-modified fragments (e.g., y11 and the His immonium ion) show the distinctive ${ }^{18} \mathrm{O}$ isotope signature (Figure 1c, insets). The presence of these spectral features unique to carbonylated peptides enables independent validation of database search results on $\mathrm{MS}^{2}$ spectra, confirming both the presence and localization of reactive carbonyl modifications within the matched peptide.

\section{Eliminating Trypsin-Catalyzed ${ }^{18} \mathrm{O}$ Exchange}

Although the proof-of-principle results in Figure 1 were encouraging, a significant potential problem existed. This problem results from the well-described proteasecatalyzed exchange of carboxyl oxygens from the Ctermini of peptides with those from the solvent [23]. Although useful for global quantitative proteomic studies [24, 25], for our purposes the potential partial incorporation of ${ }^{18} \mathrm{O}$ into the carboxy terminus of all peptides would result in all tryptic peptides with a free C-terminal carboxyl group being mass tagged, and hamper our attempts to limit such tags specifically to peptides carrying reactive carbonyl modifications. To address this issue, we compared the efficacy of several measures [26-28] to eliminate the oxygen-exchange activity of trypsin within a digest of HNE-modified myoglobin, using ${ }^{18} \mathrm{O}$ incorporation as the readout (Figure 2). For these experiments, non-HNE modified myoglobin peptides ${ }^{18} \mathrm{O}$ labeled at their $\mathrm{C}$-termini were detected by the presence of at least one ${ }^{18} \mathrm{O}$ isotopologue in the MS spectra resulting in a mass shift of $2 \mathrm{Da}$ or more. Meanwhile, HNE-modified myoglobin peptides ${ }^{18} \mathrm{O}$-labeled at both the reactive carbonyl and C-termini were detected by the presence of at least two ${ }^{18} \mathrm{O}$ isotopologues, resulting in a mass shift of $4 \mathrm{Da}$ or more.

In the absence of any measures to inactivate trypsin, the C-termini of both nonmodified and HNE-modified peptides were labeled with multiple ${ }^{18} \mathrm{O}$ molecules such that the isotope signatures remained indistinguishable (Figure 2a). Efforts to physically remove trypsin by ultrafiltration almost completely abolished the incorporation of ${ }^{18} \mathrm{O}$ into peptide C-termini (Figure $2 b$ ), and while promising, concerns about the reliability and possible sample loss of ultrafiltration devices have been documented [27, 28]. Alternatively, Hajkova and colleagues recently characterized the $\mathrm{pH}$ dependency observed for the oxygen-exchange activity of trypsin and found a substantial loss of function at more basic conditions [26]. Based on their findings, we attempted to prevent ${ }^{18} \mathrm{O}$ incorporation into the peptide $\mathrm{C}$-termini by shifting the $\mathrm{pH}$ of the ${ }^{18} \mathrm{O}$-labeling reaction to 12 , which only partially reduced the incorporation of ${ }^{18} \mathrm{O}$ into the $\mathrm{C}$-terminus of peptides (Figure 2c). Another method for inactivating trypsin described by Smith and colleagues involves boiling the samples [27, 29, 30]. However, in our hands, boiling the HNE-myoglobin digest before ${ }^{18} \mathrm{O}$-labeling did not significantly reduce ${ }^{18} \mathrm{O}$ incorporation into the C-terminus of peptides, presumably due to refolding of the enzyme back into its catalytically active state during the subsequent two-hour ${ }^{18} \mathrm{O}$-labeling reaction (Figure $2 \mathrm{~d}$ ).

Given the observed limitations of the measures above, we pursued an alternative approach which sought to exploit trypsin's ability to back-exchange the C-terminus. By adding an additional step whereby the reduced peptides were incubated in $100 \%{ }^{16} \mathrm{O}$ water supplemented with trypsin, we hypothesized that the trypsin would completely incorporate ${ }^{16} \mathrm{O}$ back into the C-terminus, while leaving the ${ }^{18} \mathrm{O}$ trapped in the reduced HNE modification unaffected. Indeed, after an overnight incubation virtually all peptides were free of ${ }^{18} \mathrm{O}$ incorporation into their $\mathrm{C}$-terminus, while the signature isotope pattern for HNE-modified peptides was preserved (Figure 2e). Given the effectiveness of this simple procedure to remove ${ }^{18} \mathrm{O}$ incorporated into the peptide C-termini of reduced peptides, we decided to incorporate it into our overall method for characterizing carbonylated peptides. Importantly, the results from these studies demonstrated our ability to limit ${ }^{18} \mathrm{O}$ incorporation to the oxygen of the reactive carbonyl, ensuring that the corresponding isotope signatures detected by mass spectrometry were specific to carbonylated peptides. 
VEADIAGHGQEVLIR

(a) Control (trypsin present)

(b) Physical removal

(c) $\mathrm{pH}$ inactivation

(d) Heat inactivation

(e) ${ }^{16} \mathrm{O}$ back-exchange
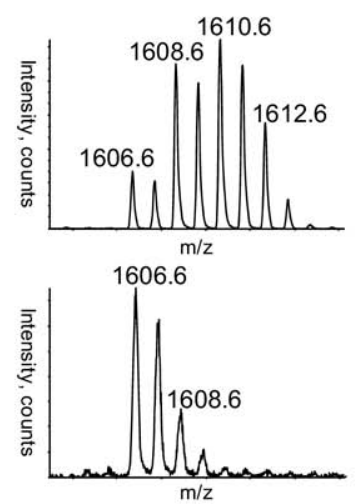

1606.61608 .6
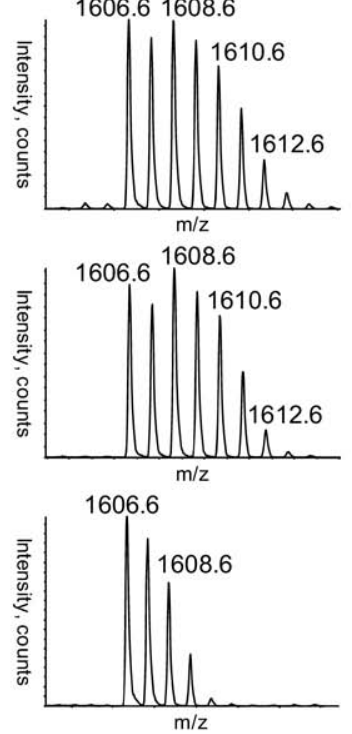

VEADIAGH\#GQEVLIR
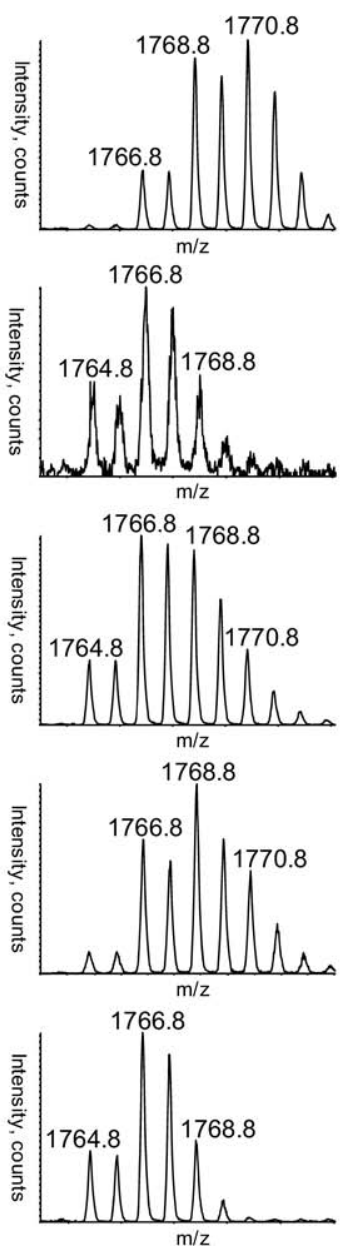

Figure 2. Comparison of methods for eliminating the oxygen-exchange activity of trypsin. A digest of HNE-modified myoglobin was incubated with $70 \% \mathrm{H}_{2}{ }^{18} \mathrm{O}$ (aqueous) after exposure to various methods for preventing the trypsin-catalyzed incorporation of ${ }^{18} \mathrm{O}$ into the carboxyl oxygens at the C-terminus of peptides. The isotope envelopes for a single peptide from the digest, in both its nonmodified and HNE-modified (\#) form as observed in a MALDI-TOF MS spectrum, are presented. (a) The digest was labeled with $70 \%{ }^{18} \mathrm{O}$ and reduced without any intervening measures for inactivating trypsin. (b) Trypsin was physically removed by ultrafiltration, and the flow-through was ${ }^{18} \mathrm{O}$-labeled $(70 \%)$ and reduced. (c) The digest was ${ }^{18} \mathrm{O}$-labeled $(70 \%)$ and reduced at a $\mathrm{pH}$ of 12 so as to inactivate trypsin's oxygen-exchange activity. (d) The digest was boiled for $15 \mathrm{~min}$ to inactivate trypsin and then labeled with $70 \%{ }^{18} \mathrm{O}$. (e) The digest was labeled with $70 \%{ }^{18} \mathrm{O}$ without any intervening measures for inactivating trypsin, vacuum centrifuged to dryness, reconstituted in $100 \%$

${ }^{16} \mathrm{O}$ water supplemented trypsin, and incubated overnight at room temperature.

Combining SPH Enrichment and ${ }^{18} \mathrm{O}$-Labeling for the Analysis of Carbonylated Peptides from

\section{Complex Mixtures}

To characterize the carbonyl proteome in complex mixtures, we previously described a front-end enrichment method based on the reversible, covalent capture and release of carbonylated peptides to an SPH reagent [20]. Here we sought to combine SPH enrichment and ${ }^{18} \mathrm{O}-$ labeling to develop an integrated method for enhancing the detection and identification of carbonylated peptides from complex mixtures. This method integrates three stages: (1) enrichment of carbonylated peptides; (2) ${ }^{18}$ O-labeling of enriched peptides; and (3) analysis of labeled peptides by high-resolution mass spectrometry (Figure 3). In the first stage, the SPH reagent, described in detail in the Materials and Methods section, is used to enrich carbonyl modified peptides from a complex mixture, in this case HNE-modified peptides from a rat skeletal muscle lysate. As we have previously described [20], HNE-modified peptides are covalently bound to the resin by formation of acid labile, covalent Schiffbase bonds. As such, both peptide capture and subsequent wash steps were conducted at neutral $\mathrm{pH}$, wherein the Schiff-base bond is stable, while the elution of the bound peptides was performed under acidic conditions. In the second stage, the enriched peptides 


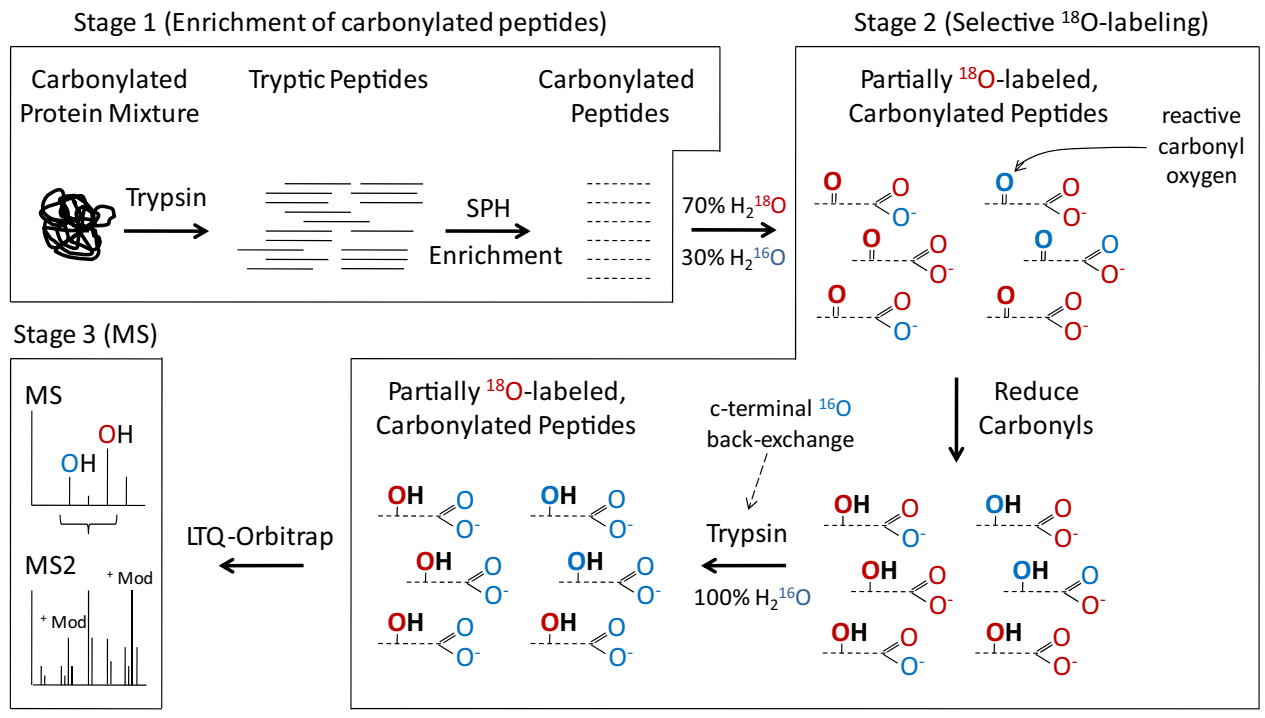

Figure 3. Scheme for the comprehensive analysis of carbonylated peptides by label-free SPH enrichment and targeted ${ }^{18} \mathrm{O}$-labeling of peptide carbonyls. Details for the enrichment, ${ }^{18} \mathrm{O}$-labeling, and high-resolution mass spectrometry analysis of carbonylated peptides are described in the Materials and Methods section.

are incubated in $70 \% \mathrm{H}_{2}{ }^{18} \mathrm{O}$ at neutral $\mathrm{pH}$, reduced with sodium borohydride, and subjected to conditions promoting the trypsin-catalyzed removal of any ${ }^{18} \mathrm{O}$ incorporated into the C-terminus of peptides during the labeling reaction. Finally, the ${ }^{18} \mathrm{O}$-labeled sample is analyzed on an LTQ-Orbitrap mass spectrometer to ensure sufficient resolution of the ${ }^{16} \mathrm{O}:{ }^{18} \mathrm{O}$ isotope signature of the carbonylated peptide precursor-ions, and to generate high quality $\mathrm{MS}^{2}$ spectra using the linear ion trap.

\section{Analysis of HNE-Treated Tissue Lysates from Rat Skeletal Muscle}

To test the value of this integrated method, we applied it to the analysis of a rat skeletal muscle tissue lysate treated with HNE. We first sought to confirm that ${ }^{18} \mathrm{O}$ labeling did not negatively affect our ability to identify HNE-modified peptides by $\mathrm{MS}^{2}$ and database searching. By comparing database matches from the same SPH enriched sample split into a non-labeled (normal ${ }^{16} \mathrm{O}$ isotope signatures) fraction, and a ${ }^{18} \mathrm{O}$-labeled fraction, we found that the presence of ${ }^{18} \mathrm{O}$ isotopologues in the MS and $\mathrm{MS}^{2}$ spectra does not impair the ability of sequence database searching to identify these peptides. In fact, the ${ }^{18} \mathrm{O}$-labeled fraction resulted in a slight increase in confident matches to HNE-modified peptides than did the non $-{ }^{18} \mathrm{O}$ labeled fraction (Supplemental Figure 1, which can be found in the electronic version of this article). Importantly, the two fractions contained a similar number of collected $\mathrm{MS}^{2}$ spectra and the same delta mass threshold was used in determining correct sequence matches for each dataset (see the Materials and Methods section). The slight improvement in the number of identifications for the ${ }^{18} \mathrm{O}$ labeled sample may be due to the increased number peaks derived from the ${ }^{18} \mathrm{O}$ isotope signatures available for selection for $\mathrm{MS}^{2}$. Regardless, these results proved that labeling with ${ }^{18} \mathrm{O}$ did not negatively affect the ability to identify HNE-modified peptides via $\mathrm{MS}^{2}$ and database searching, a crucial point to demonstrating the benefits of our method.

In total, $210 \mathrm{MS}^{2}$ spectra from the ${ }^{18} \mathrm{O}$-labeled sample were matched to 60 unique HNE-modified peptides (Supplemental Table 1) at an estimated false positive rate of $0 \%$ for matched peptides using stringent filtering of matches (see the Materials and Methods section). That the vast majority of peptides were modified at histidine residues, with very few modifications at cysteine or lysine residues, is consistent with previous in vitro modification studies [20,31,32], and is likely an artifact of the in vitro treatment conditions, rather than a bias towards histidine-modified peptides introduced by the SPH or ${ }^{18} \mathrm{O}$-labeling procedures. In the present study after ${ }^{18} \mathrm{O}$-labeling we did identify a few lysine modified peptides (Supplemental Table 1), similar in proportion to histidine-modified peptides to our previous description of the $\mathrm{SPH}$ reagent [20]. Therefore, $\mathrm{SPH}$ and ${ }^{18} \mathrm{O}$-labeling is amenable to peptides modified at residues other than histidine. As with any in vitro treatment, it is difficult to know whether the modifications identified are conserved in the in vivo environment. However, for the purposes of the objectives of the work described here, the in vitro treatment enabled us to effectively demonstrate the utility of combining ${ }^{18} \mathrm{O}$ labeling with label-free enrichment of carbonylated peptides for analysis of complex mixtures of carbonylated proteins.

One advantage of this combined method is that added information gained from ${ }^{18} \mathrm{O}$-labeling can be used to strengthen database search results. For exam- 
(a)

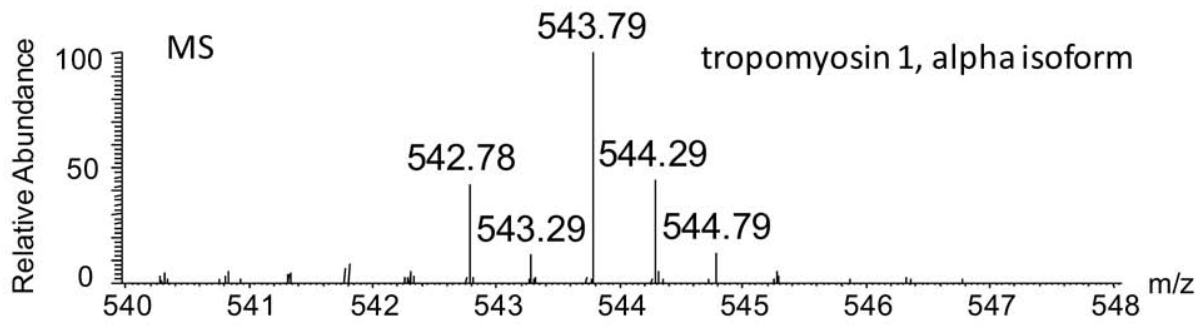

MS2 $543.79 \mathrm{~m} / \mathrm{z}$

Xcorr 3.04

$\triangle \mathrm{ppm}-1.387$
7654321 y

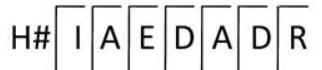

b 1234567

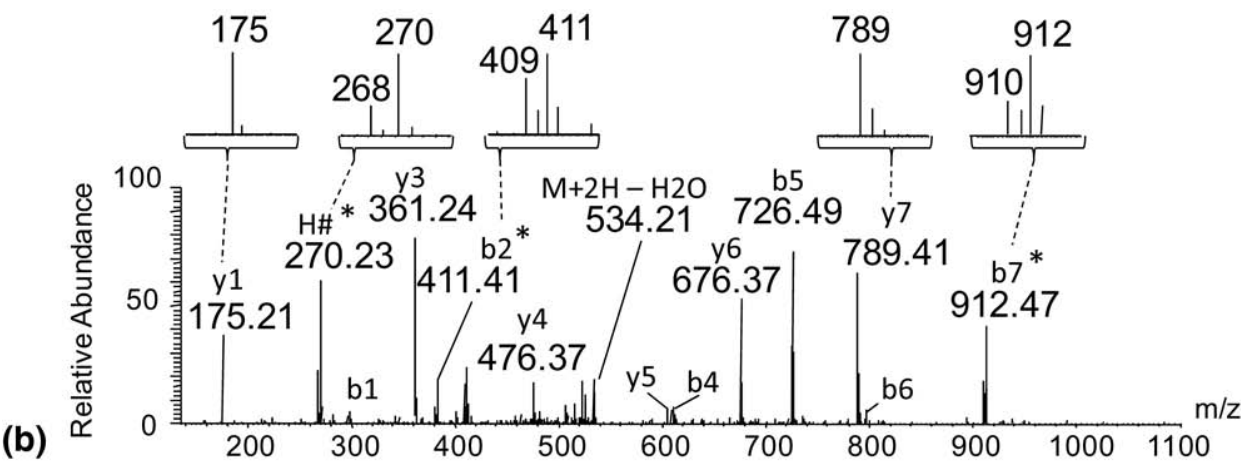

Figure 4. Example MS and $\mathrm{MS}^{2}$ spectra collected on an LTQ-Orbitrap that matched confidently to a HNE-modified peptide from a rat muscle protein, tropomyosin 1. (a) MS spectrum showing the signature isotope pattern produced by partial incorporation of ${ }^{18} \mathrm{O}$ into the doubly charged precursor-ion of a carbonylated peptide. The 542.78 and $543.79 \mathrm{~m} / \mathrm{z}$ ions represent the ${ }^{16} \mathrm{O}$ and ${ }^{18} \mathrm{O}$-labeled versions of the peptide, respectively, which appear in the expected relative abundance ratio. (b) $\mathrm{MS}^{2}$ spectrum generated by fragmenting the ${ }^{18} \mathrm{O}$-labeled isotopologue $(543.79 \mathrm{~m} / \mathrm{z})$ in the linear ion trap using an isolation width of $2 \mathrm{Da}$. The observed b- and y-ions, together with the His immonium ion, are labeled in the spectrum and shown in bold in the peptide map. The isotope envelopes for several of the fragment ions have been magnified and are inlayed above the spectrum. As predicted by the sequence, the $\mathrm{y}$-ion series does not contain ${ }^{18} \mathrm{O}$ isotopologues while the series of b-ions, as well as the His immonium ion, do. ${ }^{*} \mathrm{HNE}$ labeled fragments expected to show ${ }^{18} \mathrm{O}$ isotope signatures.

ple, the MS and MS ${ }^{2}$ spectra in Figure 4 were matched by SEQUEST to a HNE-modified peptide from tropomyosin 1 . The presence of an HNE-modification on the peptide is first supported by the isotope signature of the precursor ion where the monoisotopic and the +2 isotope appear in the expected $1: 2{ }^{16} \mathrm{O}:{ }^{18} \mathrm{O}$ ratio, specific to HNE-modified peptides (Figure $4 \mathrm{a}$ ). The preservation of the signature isotope pattern for multiple fragment ions in the $\mathrm{MS}^{2}$ spectrum indicates that both the ${ }^{16} \mathrm{O}$ and ${ }^{18} \mathrm{O}$ precursor ions entered the collision cell when using a 2.0 Da isolation width, which proved convenient for confirming the accuracy of the peptide sequence match and site of modification (Figure $4 \mathrm{~b}$, see Supplemental Figure 2 for .out file). Importantly, all the fragment ions with the expected ${ }^{18} \mathrm{O}$ isotope signatures were assigned to b-ions carrying the HNE modification, while all the y-ions, which lacked the HNE modification, were assigned to fragment ions with typical, ${ }^{16} \mathrm{O}$-only isotope signatures (Figure $4 \mathrm{~b}$, insets). The ${ }^{18} \mathrm{O}$ isotope signature was also observed for the HNE- modified immonium ion of His, further validating that the modification was mapped to the correct residue (Figure $4 b$, inset). Thus, greater confidence can be gained for carbonylated peptides identified by database matching as a result of ${ }^{18} \mathrm{O}$-labeling.

As observed with other peptide enrichment methods [33], it was very difficult to completely remove nonmodified peptides that bind the resin nonspecifically. In this case, such peptides provided a good internal control for evaluating the specificity of the ${ }^{18} \mathrm{O}$-labeling. One such example (Supplemental Figure 3) was a confidently matched non-HNE-modified peptide from the protein actinin. As predicted, neither the MS nor the $\mathrm{MS}^{2}$ spectrum contained isotope signatures reflective of ${ }^{18} \mathrm{O}$ incorporation, indicating the specificity of our method for incorporating ${ }^{18} \mathrm{O}$ within the reactive carbonyl groups.

In addition to the numerous true positive matches confirmed by ${ }^{18} \mathrm{O}$-labeling, a significant number of false negative matches were also identified by virtue of the 
(a)

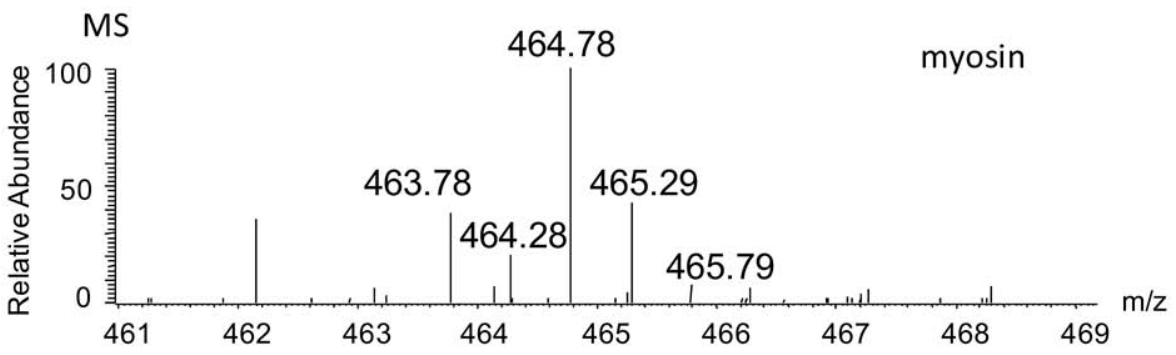

MS2

$\begin{array}{llllll}5 & 4 & 3 & 2 & 1 & y\end{array}$

Rank 12

Xcorr 2.09

$\Delta \mathrm{ppm} 0.808$

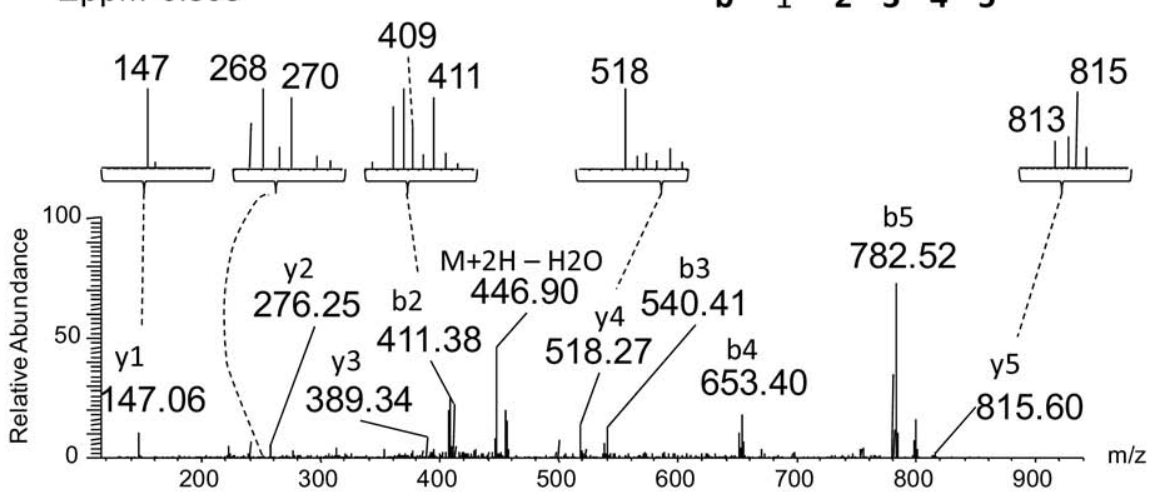

(b)

Figure 5. Utility of ${ }^{18} \mathrm{O}$-labeling for identifying HNE-modified peptides matched with low confidence and ranked low in the SEQUEST output file. The MS (a) and subsequent MS $^{2}$ spectrum (b) from a peptide incorrectly matched to a nonmodified peptide in the reverse database (i.e., a false negative). The clear presence of ${ }^{18} \mathrm{O}$ isotopologues in both spectra guided further scrutiny of the output file and lead ultimately to the correct identification of the HNE-modified peptide from myosin. *HNE labeled fragments expected to show ${ }^{18} \mathrm{O}$ isotope signatures.

presence of ${ }^{18} \mathrm{O}$ generated isotope signatures in their MS and $\mathrm{MS}^{2}$ spectra. A false negative match in this context is an MS/MS spectrum derived from an HNEmodified peptide incorrectly matched, albeit with high confidence, to a non-HNE-modified peptide sequence by the database searching program. For example, although the MS and $\mathrm{MS}^{2}$ spectra in Figure 5 clearly contain ${ }^{18} \mathrm{O}$ isotopologues, they were incorrectly matched to a nonmodified peptide in the database search. However, further scrutiny of the top 20 candidate peptide sequences matched to this $\mathrm{MS}^{2}$ spectrum using SEQUEST revealed a candidate HNE-modified peptide from myosin, an abundant protein in skeletal muscle, which was the 12th best possible match (Supplemental Figure 4). Upon inspection, the expected series of $b$ - and $y$-ions of this sequence matched nicely to the major fragment ions in the spectrum (Figure 5b). In addition, those fragment ions containing ${ }^{18} \mathrm{O}$ isotope signatures matched to $\mathrm{b}$ - and y-ions carrying the HNE modification, while $b$ - and y-ions matching to nonmodified fragment ions also lacked the ${ }^{18} \mathrm{O}$ isotope signatures. This is most clearly demonstrated when comparing the nonmodified y4 ion, to the HNE-modified y5 ion (Figure $5 \mathrm{~b}$, inset). Indeed, the agreement between ${ }^{18} \mathrm{O}$-labeled ions and expected HNE-modified fragment ions in this spectrum, together with the prominence of myosin in skeletal muscle point to very likely being the true match. Thus, the ${ }^{18} \mathrm{O}$-labeling method also complements results from sequence database searching, revealing additional $\mathrm{MS}^{2}$ spectra of modified peptides missed by the search algorithm.

Based on the false negative peptide match described above, and our past observations revealing many $\mathrm{MS}^{2}$ spectra generated from suspected HNE-modified peptides were not being identified as such by sequence database searching, we sought to further evaluate the efficiency of sequence database searching of $\mathrm{MS}^{2}$ spectra to identify modified peptides using ${ }^{18} \mathrm{O}$ incorporation. Upon manual inspection of the LC run for the HNE-labeled rat skeletal muscle sample, it was clear that there were many more ${ }^{18} \mathrm{O}$ isotope signatures for peptide precursors selected for $\mathrm{MS}^{2}$ than were not identified by database searching. As an example, a representative MS spectrum is shown in Supplemental Figure 5. In addition to ions with typical isotope patterns (corresponding to nonspecifically bound background peptides), many more with atypical ${ }^{18} \mathrm{O}$ isotope signatures indicative of HNE-modified peptides were observed, as detailed in this figure. Of the nine isotope signatures consistent with ${ }^{18} \mathrm{O}$ labeling, three were not 
selected for $\mathrm{MS}^{2}$, and of the six selected for $\mathrm{MS}^{2}$ only one was confidently matched to an HNE-modified peptide. These findings suggested that $\mathrm{MS}^{2}$ combined with sequence database searching performed relatively poorly at identifying HNE-modified peptides.

Given our observations above based on a manual analysis of representative data, we sought to make use of the information provided by ${ }^{18} \mathrm{O}$ labeling and investigate more systematically our ability to identify HNEmodified peptides via $\mathrm{MS}^{2}$ and sequence database searching. For this, we created software that automati-

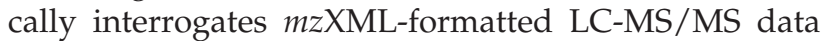
in search of unique isotope signatures attributable to partial ${ }^{18} \mathrm{O}$ incorporation at reactive carbonyls. The software identified ion clusters in MS and $\mathrm{MS}^{2}$ spectra that adhered to strict $\mathrm{m} / \mathrm{z}$ spacing and relative abundance constraints expected for ${ }^{18} \mathrm{O}$-labeled peptide isotopologues (described in detail in the Materials and Methods section).

We evaluated the specificity of our software for detecting ${ }^{18} \mathrm{O}$ isotope signatures by applying the software to a non- ${ }^{18} \mathrm{O}$-labeled, negative control sample. This negative control sample was a portion of the same enriched, HNE-modified peptides derived from the rat muscle homogenate used for testing our ${ }^{18} \mathrm{O}$ incorporation method, except the ${ }^{18} \mathrm{O}$-labeling was omitted. The negative control sample was analyzed using the same $\mu \mathrm{LC}-\mathrm{MS} / \mathrm{MS}$ method on the LTQ-Orbitrap as was the ${ }^{18} \mathrm{O}$-labeled sample, expecting that detected peptides from the negative control should show "normal" ${ }^{16} \mathrm{O}$ isotope signatures, and would thus not be detected by our software.

For our analysis, we focused on only those peptides selected for $\mathrm{MS}^{2}$ throughout our chromatographic run. We started with relaxed criteria, requiring our software to detect an ${ }^{18} \mathrm{O}$ isotope signature in the MS spectrum, and only one ${ }^{18} \mathrm{O}$ isotope signature in the resulting $\mathrm{MS}^{2}$ spectrum. Using these relaxed criteria, we estimated a false-positive rate (FPR) of $8.5 \%$ for detecting ${ }^{18} \mathrm{O}$ labeled HNE-modified peptides (Table 1). As a point of

Table 1. Measuring the false positive rate (FPR) for identification of ${ }^{18} \mathrm{O}$-labeled $\mathrm{MS}^{2}$ spectra by our software

\begin{tabular}{|c|c|c|c|}
\hline \multirow{2}{*}{$\begin{array}{l}\text { Minimum no. of } \\
{ }^{18} \mathrm{O} \text {-labeled fragment } \\
\text { ions in } \mathrm{MS}^{2} \\
\text { spectrum }\end{array}$} & \multicolumn{2}{|c|}{$\begin{array}{l}\text { No. of } \mathrm{MS}^{2} \text { spectra } \\
\text { determined by software } \\
\text { to be }{ }^{18} \mathrm{O} \text {-labeled }\end{array}$} & \multirow[b]{2}{*}{$\begin{array}{c}\text { FPR* } \\
(\%)\end{array}$} \\
\hline & $\begin{array}{l}{ }^{18} \mathrm{O}-\text {-labeled } \\
\text { sample }\end{array}$ & $\begin{array}{c}\text { Non- }{ }^{18} \mathrm{O} \text { labeled } \\
\text { control }\end{array}$ & \\
\hline 1 & 1002 & 85 & 8.5 \\
\hline 3 & 336 & 7 & 2.1 \\
\hline
\end{tabular}

*The FPR of ${ }^{18} \mathrm{O}$ labeled peptides identified by our software was measured by dividing the number of ${ }^{18} \mathrm{O}$-labeled $\mathrm{MS}^{2}$ spectra from the non- ${ }^{18} \mathrm{O}$-labeled control by the number identified in the ${ }^{18} \mathrm{O}$-labeled sample. While requiring that the precursor-ion appears as an ${ }^{18} \mathrm{O}$ isotope signature, increasing the minimum number of ${ }^{18} \mathrm{O}$ isotope signatures in the $\mathrm{MS}^{2}$ spectra used by the software to identify ${ }^{18} \mathrm{O}$ labeled $\mathrm{MS}^{2}$ spectra from one (relaxed) to three (stringent) product ions reduces the FPR to acceptable levels. ${ }^{18} \mathrm{O}$ isotope signatures are defined in the text. clarification, this estimated FPR refers to the ability of our software program to identify peptides carrying ${ }^{18} \mathrm{O}$ isotope signatures within MS or $\mathrm{MS}^{2}$ spectra, and not the FPR relating to peptide sequence matches obtained by sequence database searching. This FPR estimation was because for a comparable number of total $\mathrm{MS}^{2}$ scans ( $\sim 8500 \mathrm{MS}^{2}$ scans) 85 negative control MS ${ }^{2}$ spectra were identified by our software as being ${ }^{18} \mathrm{O}$ isotope labeled compared with 1002 from the ${ }^{18} \mathrm{O}$-labeled sample. Therefore, we estimated that 85 of the $1002 \mathrm{MS}^{2}$ spectra $(8.5 \%)$ from the sample were also false positives. To lower the FPR and generate a more conservative estimate of the number of ${ }^{18} \mathrm{O}$-labeled spectra in the dataset, we tightened the criteria the software uses to identify ${ }^{18} \mathrm{O}$-labeled spectra by requiring that all acceptable $\mathrm{MS}^{2}$ spectra contain a minimum of three fragment ions with ${ }^{18} \mathrm{O}$ isotope signatures. These more stringent criteria produced seven and $336 \mathrm{MS}^{2}$ spectra from the negative control and ${ }^{18} \mathrm{O}-$ labeled sample, respectively, which corresponds to a FPR of $2.1 \%$, and demonstrates the specificity of our software program for detecting ${ }^{18} \mathrm{O}$-labeled, carbonylated peptides.

To evaluate the efficiency by which HNE-modified peptides are identified by database searching of $\mathrm{MS}^{2}$ spectra, we compared the $\mathrm{MS}^{2}$ spectra matched to HNE-peptides by sequence database searching with those identified by the software as being ${ }^{18} \mathrm{O}$-labeled. Comparison of the database matched spectra against those deemed ${ }^{18} \mathrm{O}$-labeled using the relaxed software criteria revealed significant overlap (Figure 6a). This indicates that ${ }^{18} \mathrm{O}$-labeling complements the use of $\mathrm{MS}^{2}$ and database searching to detecting additional HNEmodified peptides from the mass spectrometry data. Assuming the total combined spectra (both those confidently matched to peptides by $\mathrm{MS}^{2}$ and database searching and those additional spectra identified by our software) provide an estimate of the "true" number of $\mathrm{MS}^{2}$ spectra derived from carbonylated peptides, the efficiency by which database searching matched $\mathrm{MS}^{2}$ spectra to carbonylated peptides in our sample was estimated to be $20 \%$ (210 total database matched spectra/1074 total combined spectra). It should be noted that this dataset includes a relatively high.

FPR $(8.5 \%)$ for the detection of ${ }^{18} \mathrm{O}$-labeled spectra by our software, indicating that the remaining 864 spectra in the dataset is a slight overestimation of the number of ${ }^{18} \mathrm{O}$-labeled $\mathrm{MS}^{2}$ spectra missed by the database search, and thus $20 \%$ probably slightly underestimates the database search efficiency.

A more conservative measure of database searching of $\mathrm{MS}^{2}$ spectra performance was achieved by comparing the $\mathrm{MS}^{2}$ spectra matched to HNE-modified peptides against the ${ }^{18} \mathrm{O}$-labeled $\mathrm{MS}^{2}$ spectra identified using the more stringent criteria (Figure $6 \mathrm{~b}$ and Supplemental Table 2). Compared to the number of proteins identified by our software using the relaxed criteria (Figure 6a), the more stringent criteria excluded a significant number of database matched HNE-modified peptides that were marked as ${ }^{18} \mathrm{O}$-labeled using the relaxed criteria. 


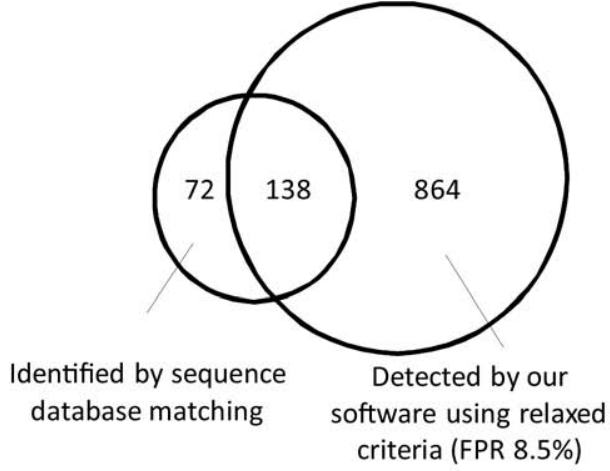

(a)
${ }^{18}$ O-labeled peptides

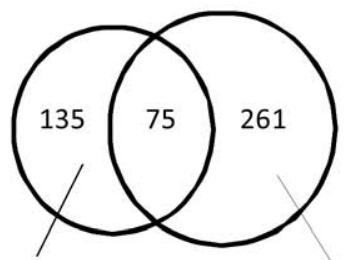

Identified by sequence Detected by our database matching software using strict criteria (FPR 2.1\%)

(b)

${ }^{18} \mathrm{O}-$-labeled peptides

Figure 6. Comparison of $\mathrm{HNE}$-modified $\mathrm{MS}^{2}$ spectra identified via sequence database searching and ${ }^{18} \mathrm{O}$-labeled $\mathrm{MS}^{2}$ spectra from ${ }^{18} \mathrm{O}$-labeled sample. $\mathrm{MS}^{2}$ spectra confidently matched to HNE-peptides via sequence database searching were compared against ${ }^{18} \mathrm{O}$-labeled $\mathrm{MS}^{2}$ spectra identified by our software using either relaxed (a), or stringent (b) criteria. Details of the criteria used are provided in the text.

Interestingly, the $\mathrm{MS}^{2}$ spectra from peptide ions with charge states of three and higher were disproportionately omitted from the resulting dataset following application of these stricter criteria (Supplemental Table 3). One reason for this bias may be the presence of multiply charged fragment ions in the $\mathrm{MS}^{2}$ spectra, whose ${ }^{18} \mathrm{O}$ isotope signatures are not well resolved in the low-resolution LTQ ion trap. Regardless of the reason, the 261 proteins indicated in Figure $6 \mathrm{~b}$ most likely underestimates the true number of $\mathrm{MS}^{2}$ spectra from HNE-modified peptides that were identified as ${ }^{18} \mathrm{O}$-labeled by our software, but missed by the database search. As such, the resulting efficiency of database search performance of $45 \%$ (210 total database matched spectra/471 total combined spectra) likely overestimates the true value.

Given the confident identification of somewhere between $20 \%$ and $45 \%$ of HNE-peptides selected for $\mathrm{MS}^{2}$, two questions arise: what limits the identification of these modified peptides, and how can it be improved? One potential limiting factor may be unexpected fragmentation of the HNE group from both precursor and fragment ions, which could complicate analysis. Distinct from neutral-loss, such ill-defined fragmentations are beyond the scope of this study and warrant further investigation. Another possible limiting factor is that the ${ }^{18} \mathrm{O}$ isotope signature observed for some peptides may result from the incorporation of ${ }^{18} \mathrm{O}$ into the C-terminus of peptides, despite our efforts to prevent this. However, we discounted this possibility by including in the database search a differential mass shift on the peptide C-terminus that accounts for ${ }^{18} \mathrm{O}$ incorporation, which showed a negligible number of matches to C-terminal modified peptides (data not shown). The presence of other modifications on HNEmodified peptides (e.g. oxidations) not accounted for in the sequence database search may also contribute to the low efficiency of identifications. Along with these pos- sible additional modifications, the potential for unknown chemical modifications introduced by reducing the sample with sodium borohydride may also be of concern. However, proof-of-principle studies on our standard protein indicated that unexpected peaks resulting from additional modifications do not appear following reduction.

Several avenues of study may improve our ability to identify HNE and other carbonyl-modified peptides. Studies directed towards defining possible unconventional CID fragmentation patterns unique to HNE and other reactive carbonyls would be highly valuable. Alternatively, fragmentation of carbonylated peptides by "softer" methods (ETD and ECD) may provide a way to preserve the fragmented peptide in its modified form, thus decreasing the complexity of the spectra and presumably increasing the efficiency by which correct identifications are made. Indeed, a recent study has coupled our SPH enrichment method with ECD analysis, showing the promise of alternative fragmentation methods for analysis of HNE-modified peptides [34]. Investigations into the relative effectiveness of instruments other than the LTQ-Orbitrap (e.g., MALDI-TOF/ TOF) instruments may also illuminate instrumentspecific differences. Notably, our ${ }^{18} \mathrm{O}$ method should provide a valuable tool for these future studies seeking a better understanding of the factors mediating the identification of carbonyl-modified peptides using $\mathrm{MS}^{2}$ and sequence database searching.

\section{Conclusions}

We have described a new method for improving the detection and identification of carbonylated peptides by mass spectrometry based on partial ${ }^{18} \mathrm{O}$-labeling, adding a valuable tool for redox proteomics. We have shown the effectiveness of this method for confirming HNE-modified peptides matched by sequence database 
searching, for identifying false negative matches, and for detecting modified peptides not selected for $\mathrm{MS}^{2}$ fragmentation. Compared with other diagnostic ions used to screen for carbonylated peptides, ${ }^{18} \mathrm{O}$-labeling should enjoy greater applicability and provide more information. For example, unlike the immonium ion for His HNE-adducts $(266 \mathrm{~m} / \mathrm{z})$, or the dehydrated product of HNE $(139 \mathrm{~m} / \mathrm{z})$ often observed for HNE-modified peptides $[20,35]$, the ${ }^{18} \mathrm{O}$ isotope signatures are not limited to a specific adduct of a given reactive carbonyl, nor even to a single class of reactive carbonyls. Although still needing empirical confirmation, our method should therefore aid in proteomic studies spanning the wide variety of modifications that encompass protein carbonylation. One potential concern of this partial isotope labeling approach is that it effectively divides signal intensity across two ions, which may prove limiting when analyzing in vivo samples. However, this problem could be addressed by developing a directed acquisition of $\mathrm{MS}^{2}$ data that targets only the most intense ion within ${ }^{18} \mathrm{O}$ isotope signatures. Finally, our software developed for the systematic identification of ${ }^{18} \mathrm{O}$-labeled peptides should have value for investigators undertaking proteomic studies of carbonylation, for example as it relates to aging and disease progression, and for those seeking to better understand and improve the characterization of carbonylated peptides using mass spectrometry. It operates on the opensource $m z X M L$ file format, making it compatible with all mass spectrometers offering high mass accuracy and resolution. The software and code is available on request.

\section{Acknowledgments}

The authors thank the Center for Mass Spectrometry and Proteomics at the University of Minnesota for instrument access and maintenance, in particular Matt Stone for his assistance with operation of the LTQ-Orbitrap. They also thank the Minnesota Supercomputing Institute for maintenance and administration of the SEQUEST cluster and related software. The authors acknowledge funding in part for this work by grant NIA AG017768 (L.V.T.).

\section{Appendix A Supplementary Material}

Supplementary material associated with this article may be found in the online version at doi:10.1016/ j.jasms.2010.03.029.

\section{References}

1. Dalle-Donne, I.; Giustarini, D.; Colombo, R.; Rossi, R.; Milzani, A. Protein Carbonylation in Human Diseases. Trends Mol. Med. 2003, 9, 169-176.

2. Grimsrud, P. A.; Xie, H.; Griffin, T. J.; Bernlohr, D. A. Oxidative Stress and Covalent Modification of Protein with Bioactive Aldehydes. J. Biol. Chem. 2008, 283, 21837-21841.

3. Dalle-Donne, I.; Scaloni, A.; Giustarini, D.; Cavarra, E.; Tell, G.; Lungarella, G.; Colombo, R.; Rossi, R.; Milzani, A. Proteins as Biomarkers of Oxidative/Nitrosative Stress in Diseases: The Contribution of Redox Proteomics. Mass Spectrom. Rev. 2005, 24, 55-99.
4. Berlett, B. S.; Stadtman, E. R. Protein Oxidation in Aging, Disease, and Oxidative Stress. J. Biol. Chem. 1997, 272, 20313-20316.

5. Requena, J. R.; Chao, C. C.; Levine, R. L.; Stadtman, E. R. Glutamic and Aminoadipic Semialdehydes are the Main Carbonyl Products of MetalCatalyzed Oxidation of Proteins. Proc. Natl. Acad. Sci. U.S.A. 2001, 98, 69-74.

6. Chevion, M.; Berenshtein, E.; Stadtman, E. R. Human Studies Related to Protein Oxidation: Protein Carbonyl Content as a Marker of Damage. Free Radical Res. 2000, 33(Suppl.), S99-S108.

7. Monnier, V. M. Nonenzymatic Glycosylation, the Maillard Reaction, and the Aging Process. J. Gerontol. 1990, 45, B105-B111.

8. Sies, H. Role of Reactive Oxygen Species in Biological Processes. Klin. Wochenschr. 1991, 69, 965-968.

9. Carini, M.; Aldini, G.; Facino, R. M. Mass Spectrometry for Detection of 4-Hydroxy-trans-2-Nonenal (HNE) Adducts with Peptides and Proteins. Mass Spectrom. Rev. 2004, 23, 281-305.

10. Mirzaei, H.; Baena, B.; Barbas, C.; Regnier, F. Identification of Oxidized Proteins in Rat Plasma Using Avidin Chromatography and Tandem Mass Spectrometry. Proteomics 2008, 8, 1516-1527.

11. Grimsrud, P. A.; Picklo, M. J., Sr.; Griffin, T. J.; Bernlohr, D. A. Carbonylation of Adipose Proteins in Obesity and Insulin Resistance: Identification of Adipocyte Fatty Acid-Binding Protein as a Cellular Target of 4-Hydroxynonenal. Mol. Cell. Proteom. 2007, 6, 624-637.

12. Mirzaei, H.; Regnier, F. Affinity Chromatographic Selection of Carbonylated Proteins Followed by Identification of Oxidation Sites Using Tandem Mass Spectrometry. Anal. Chem. 2005, 77, 2386-2392.

13. Soreghan, B. A.; Yang, F.; Thomas, S. N.; Hsu, J.; Yang, A. J. HighThroughput Proteomic-Based Identification of Oxidatively Induced Protein Carbonylation in Mouse Brain. Pharm. Res. 2003, 20, 1713-1720.

14. Meany, D. L.; Xie, H.; Thompson, L. V.; Arriaga, E. A.; Griffin, T. J. Identification of Carbonylated Proteins from Enriched Rat Skeletal Muscle Mitochondria Using Affinity Chromatography-Stable Isotope Labeling and Tandem Mass Spectrometry. Proteomics 2007, 7, 11501163.

15. Codreanu, S. G.; Zhang, B.; Sobecki, S. M.; Billheimer, D. D.; Liebler, D. C. Global Analysis of Protein Damage by the Lipid Electrophile 4-Hydroxy-2-nNonenal. Mol. Cell. Proteom. 2009, 8, 670-680.

16. Thomas, S. N.; Soreghan, B. A.; Nistor, M.; Sarsoza, F.; Head, E.; Yang, A. J. Reduced Neuronal Expression of Synaptic Transmission Modulator HNK-1/Neural Cell Adhesion Molecule as a Potential Consequence of Amyloid $\beta$-Mediated Oxidative Stress: A Proteomic Approach. J. Neurochem. 2005, 92, 705-717.

17. Yi, E. C.; Li, X. J.; Cooke, K.; Lee, H.; Raught, B.; Page, A.; Aneliunas, V. Hieter, P.; Goodlett, D. R.; Aebersold, R. Increased Quantitative Proteome Coverage with (13)C/(12)C-Based, Acid-Cleavable IsotopeCoded Affinity Tag Reagent and Modified Data Acquisition Scheme. Proteomics 2005, 5, 380-387.

18. Chavez, J.; Wu, J.; Han, B.; Chung, W. G.; Maier, C. S. New Role for an Old Probe: Affinity Labeling of Oxylipid Protein Conjugates by N'Amino-Oxymethylcarbonylhydrazino d-Biotin. Anal. Chem. 2006, 78, 6847-6854.

19. Han, B.; Stevens, J. F.; Maier, C. S. Design, Synthesis, and Application of a Hydrazide-Functionalized Isotope-Coded Affinity Tag for the Quantification of Oxylipid-Protein Conjugates. Anal. Chem. 2007, 79, 33423354 .

20. Roe, M. R.; Xie, H.; Bandhakavi, S.; Griffin, T. J. Proteomic Mapping of 4-Hydroxynonenal Protein Modification Sites by Solid-Phase Hydrazide Chemistry and Mass Spectrometry. Anal. Chem. 2007, 79, 37473756

21. Sun, G.; Anderson, V. E. A Strategy for Distinguishing Modified Peptides Based on Post-Digestion ${ }^{18} \mathrm{O}$ Labeling and Mass Spectrometry. Rapid Commun. Mass Spectrom. 2005, 19, 2849-2856.

22. Ichihashi, K.; Osawa, T.; Toyokuni, S.; Uchida, K. Endogenous Formation of Protein Adducts with Carcinogenic Aldehydes. J. Biol. Chem. 2001, 276, 23903-23913.

23. Schnolzer, M.; Jedrzejewski, P.; Lehmann, W. D. Protease-catalyzed Incorporation of ${ }^{18} \mathrm{O}$ into Peptide Fragments and Its Application for Protein Sequencing by Electrospray and Matrix-Assisted Laser Desorption/Ionization Mass Spectrometry. Electrophoresis 1996, 17 , 945-953.

24. Heller, M.; Mattou, H.; Menzel, C.; Yao, X. Trypsin Catalyzed ${ }^{16} \mathrm{O}-$ to${ }^{18} \mathrm{O}$ Exchange for Comparative Proteomics: Tandem Mass Spectrometry Comparison Using MALDI-TOF, ESI-QTOF, and ESI-Ion Trap Mass Spectrometers. J. Am. Soc. Mass Spectrom. 2003, 14, 704-718.

25. Yao, X.; Freas, A.; Ramirez, J.; Demirev, P. A.; Fenselau, C. Proteolytic ${ }^{18} \mathrm{O}$ Labeling for Comparative Proteomics: Model Studies with Two Serotypes of Adenovirus. Anal. Chem. 2001, 73, 2836-2842.

26. Hajkova, D.; Rao, K. C.; Miyagi, M. pH Dependency of the Carboxyl Oxygen Exchange Reaction Catalyzed by Lysyl Endopeptidase and Trypsin. J. Proteome Res. 2006, 5, 1667-1673.

27. Petritis, B.; Qian, W. J.; Camp, D.; Smith, R. A Simple Procedure for Effective Quenching of Trypsin Activity and Prevention of ${ }^{18} \mathrm{O}$-Labeling Back-Exchange. J. Proteome Res. 2009, 8, 2157-2163.

28. Sevinsky, J. R.; Brown, K. J.; Cargile, B. J.; Bundy, J. L.; Stephenson, J. L. Jr. Minimizing back exchange in ${ }^{18} \mathrm{O} /{ }^{16} \mathrm{O}$ Quantitative Proteomics Experiments by Incorporation of Immobilized Trypsin into the Initial Digestion Step. Anal. Chem. 2007, 79, 2158-2162.

29. Liu, T.; Qian, W. J.; Strittmatter, E. F.; Camp, D. G. II; Anderson, G. A. Thrall, B. D.; Smith, R. D. High-Throughput Comparative Proteome 
Analysis Using a Quantitative Cysteinyl-Peptide Enrichment Technology. Anal. Chem. 2004, 76, 5345-5353.

30. Qian, W. J; Monroe, M. E.; Liu, T. Jacobs, J. M.; Anderson, G. A.; Shen, Y.; Moore, R. J.; Anderson, D. J.; Zhang, R.; Calvano, S. E.; Lowry, S. F.; Xiao, W.; Moldawer, L. L.; Davis, R. W.; Tompkins, R. G.; Camp, D. G. 2nd; Smith, R. D. Quantitative Proteome Analysis of Human Plasma Following In Vivo Lipopolysaccharide Administration Using ${ }^{16} \mathrm{O} /{ }^{18} \mathrm{O}$ Labeling and the Accurate Mass and Time Tag Approach. Mol. Cell. Proteom. 2005, 4, 700-709.

31. Fenaille, F.; Parisod, V.; Tabet, J. C.; Guy, P. A. Carbonylation of Milk Powder Proteins as a Consequence of Processing Conditions. Proteomics 2005, 5, 3097-3104.

32. Orioli, M.; Aldini, G.; Beretta, G.; Facino, R. M.; Carini, M. LC-ESIMS/MS Determination of 4-Hydroxy-trans-2-Nonenal Michael Adducts with Cysteine and Histidine-Containing Peptides as Early Markers of Oxidative Stress in Excitable Tissues. J. Chromatogr. B Anal. Technol. Biomed. Life Sci. 2005, 827, 109-118.

33. Ranish, J. A.; Yi, E. C.; Leslie, D. M.; Purvine, S. O.; Goodlett, D. R.; Eng, J.; Aebersold, R. The Study of Macromolecular Complexes by Quantitative Proteomics. Nat. Genet. 2003, 33, 349-355.

34. Rauniyar, N. Stevens, S. M. Prokai-Tatrai, K. Prokai, L. Characterization of 4-Hydroxy-2-Nonenal-Modified Peptides by Liquid ChromatographyTandem Mass Spectrometry Using Data-Dependent Acquisition: Neutral Loss-Driven MS ${ }^{3}$ Versus Neutral Loss-Driven Electron Capture Dissociation. Anal. Chem. 2009, 81, 782-789.

35. Bolgar, M. S.; Gaskell, S. J. Determination of the Sites of 4-Hydroxy-2Nonenal Adduction to Protein by Electrospray Tandem Mass Spectrometry. Anal. Chem. 1996, 68, 2325-2330. 